\title{
Contributions of the Science Museums for Teacher Education in Brazil
}

\author{
Daniela Franco Carvalho \\ Federal University of Uberlandia, Biology Institute, Minas Gerais, Brazil \\ Email: danielafranco@ufu.br
}

How to cite this paper: Carvalho, D. F. (2021). Contributions of the Science Museums for Teacher Education in Brazil. Creative Education, 12, 1079-1089. https://doi.org/10.4236/ce.2021.125080

Received: April 6, 2021

Accepted: May 25, 2021

Published: May 28, 2021

Copyright (C 2021 by author(s) and Scientific Research Publishing Inc. This work is licensed under the Creative Commons Attribution International License (CC BY 4.0).

http://creativecommons.org/licenses/by/4.0/

\begin{abstract}
In this article we discuss the main contributions of the Brazilian Science Museums for teacher education of different levels and areas. The education activities developed in these non-formal places involve the update of science contents, production of teaching resources, socialization of knowledge among peers and between teachers and the technical staff of these places, and teaching advice for the development of science projects at schools. This variety of options of assistance for teacher education is based on the diversity of public and demands. Generally the Brazilian Science Museums suit seeking education proposals to teachers who attend these sites and using them as teaching resources to complement the lessons in school. Some proposals for training are the need to give teachers the space of the museum and the opportunities for interaction with visitors. Other programs seek to facilitate the relationship with the teacher and the school museum. Others seek to include teachers in the debate on the popularization of science and technology in the country, permeating the bias of education in science and consolidation of citizenship.
\end{abstract}

\section{Keywords}

Teacher Education, Informal Science Institutions, Science Museum, Science Disclose, Non-Formal Places

\section{Introduction}

The continuing teacher education has been advocated by researchers in education, regardless of the theoretical and methodological lines they follow, because of the need to surpass deficiencies in training, update contents and expand the vision of the world and the possibilities of teaching activities. Thus, the central issue is not the validity of continuing education, but the way it is being offered to teachers. Several authors highlight the provision of inadequate proposals, which 
contribute little to the process of teacher learning or even end up discouraging the teaching activities.

The professional development of a teacher is a continuous process, where the moment of entry into the initial course is only a milestone on a path of growth of the teacher. The constituents of the life history of the teacher will combine the knowledge of a given specific area, pedagogical theories and evidence from the practical teaching, which together form the basis on which the profession will be supported (Selles, 2002).

New visions and proposals in the field of teachers' education indicate a need to include the teacher as a participant in the process of formation, allowing the exchange of experiences with peers and university researchers for a thorough and based discussion on educational and social problems that affect the teaching activities. Patterson (2021) using interviews, observations, and artifacts analyzed the pedagogies historians, archivists, and museum educators when adopting the role of teacher educators, whose results offer possibilities for a collaborative and site-based structure of teacher education.

For Pierson and Neves (2001), training of teachers should focus on the commitment of teachers facing the construction of citizenship, which means to overcome the fragmented view of knowledge and to build projects of interdisciplinary education.

Specifically on the continuing education of science teachers, the works of Vianna and Carvalho (2000) and Selles (2002) highlight the importance of scientific content and knowledge updating coupled with scientific study and research of the educational context.

For Vianna and Carvalho (2000), proposals for science teacher education must involve: 1) updated contents in science and teaching, providing knowledge updating and deepening to the participants; 2) immersion in the scientific environment, providing a building vision of science and maintaining a permanent contact with the producers of scientific knowledge; and 3) research on teaching practice, for reflection and application of current and relevant content to the different levels of education and to the specific characteristics of students.

The informal science environments provide a virtually untapped potential to engage teachers in professional enhancement that integrates professionalism, content, and pedagogy (Melber \& Cox-Petersen, 2005). The Science Museums are open to such proposals, since the teachers can update science content and discuss it with professionals who work at these sites. Tran (2006) studied the ways educators teach science and their goals underlying those actions, aiming to highlight the educators' contributions to school children's experiences on field trips through rich descriptions of their teaching in museums.

Because of approaching scientific content through interactive exhibits, teachers and Science Education researchers began to see in the Science Museums conditions to operate as a supplement to education promoted in schools, since the various interactions between students and the apparatus of this type of exposure increase the curiosity and stimulate the investigative behavior, which can 
be the basis of ideas and activities for the classroom (Gouvêa et al., 2001). Actually, visits to museums are an important part of elementary school science teaching (Mortensen \& Smart, 2007).

With the national policy for popularization of Science of the Brazilian Ministry of Science and Technology, fostered in part by the State Research Support Foundations, an increasing supply of resources has prompted the creation, consolidation and improvement of Science Museums throughout the country. Therefore, most cities have Science Museums and more teachers will have access to these places of scientific disclose, creating a demand for differentiated professional development activities in the area of sciences.

Institutions of higher education (IHE) and informal science institutions (ISI) both contribute to the improvement of science learning and teaching through professional development (PD) in several countries such as the United States and the UK (Astor-Jack et al., 2007). In Brazil, the informal science institutions had been acted as science discloses and educational settings. The emergence of the Science Museum is directly related with processes of formal education and more specifically with governmental programs from the 1950 s, created to facilitate the improvement of school science education in the country (Fahl, 2003).

With regard to the role of Science Museums, their configuration is not only of a place of science and technology information, but also of formation of human resources, that look for updating in the area, exchange experiences in the field of science disclose and also seek basic knowledge on the links among science, technology and society. Students of different levels usually develop traineeships and research projects in scientific areas in these settings and teachers of all levels of education seek teaching and methodology support at museums.

These settings are very different, both regarding the physical structure (building and facilities), the presentation of exhibits, the size and composition of the staff, and also the input of financial resources, social-educational activities and professional development programs for teachers.

However, these informal science places have been little studied with regard to the professional development of teachers, a similar situation in many countries, since most studies focus on science museums in the learning of science by students and visitors in general (Melber \& Cox-Petersen, 2005).

Phillips, Finkelstein and Wever-Frerichs (2007) conducted extensive research on the informal science institution programs currently provide to support K-12 science education, particularly in the area of teacher professional development in the United States. Holliday, Lederman and Lederman (2014) studied a life science course that was offered at and taught by education staff of a large informal science institution. The researcher developed a content test based on the course instructional objectives and lessons provided by education staff and all participating elementary and middle school teachers $(n=62)$ were asked to complete an evaluation at the end of each day's session. Teacher responses were extremely positive, but teachers' gains in science content knowledge were not as 
strong as they had perceived. In Brazil, a similar study was conducted in 11 Science Museums, with identification of 14 educational programs for teachers, as described in Jacobucci et al. (2009).

Although many informal science institutions in the world offer some type of professional development for teachers, the results of such programs have not been widely disseminated (Melber \& Cox-Petersen, 2005). An example is the teacher training course "The use of Science Centres as resources for science teaching in elementary education" from the Portuguese Agency for Scientific and Technological Culture "Ciência Viva" (Faria, 2012).

The purpose of this study was to investigate how some Science Museums have contributed to the teachers' formation in Brazil, from analysis of educational programs developed by these informal science institutions.

\section{Methodological Development}

To achieve the research objectives, we selected 11 Science Museums from around the country, associated with $\mathrm{ABCMC}^{1}$ that had been done actions to improve teacher education. These institutions were visited and data were obtained from five basic sources: 1) Internet sites of Science Museums in which all information is available on the various activities of science disclose; 2) bibliographic material produced by the museums; 3 ) annual reports of the Science Museums; 4) interviews with managers and members of staff, based on a semi-structured questionnaire, and 5) written records of observations and photos of the museums and their exhibits.

This research was delineated as a case study (Lüdke \& André 1986; Laville \& Dionne 1999), which makes use of various sources of information and a variety of data collected at different times and situations, which information can confirm or reject hypotheses.

The contributions from Science Museums for the continuing education of teachers are discussed through examples of the programs in these spaces, based on theoretical concepts and characteristics of each model of teacher education that support the proposed program. The analysis is presented on four topics: update of Science contents, production of teaching resources, teaching advice and socialization of knowledge.

\section{Results}

\subsection{Update of Science Contents}

The Brazilian Science Museums offer activities to update the Science contents to teachers in the form of courses, workshops and lectures. These findings are similar to those of Melber and Cox-Petersen (2005). These authors report that professional development programs within museums can take many forms. Some of them offer on-site programs that last from an afternoon to a collaboration for

${ }^{1}$ Associação Brasileira de Centros e Museus de Ciências (Brazilian Association of Science Centers and Science Museums)—http://www.abcmc.org.br. 
several months.

The update help teachers as they provide information newly produced in universities and national and international research institutes, providing a direct disclosure of knowledge generated by academic research, without distortion by the media.

The contact with experts in certain areas of Science, albeit in a limited way by time and by the characteristics of the activities, can help the teacher to obtain information directly from those who experience the process of scientific production. Melber and Cox-Petersen (2005) noted the importance placed by teachers on the opportunity to interact with museum scientists. However, programs that rely on experts who take a position of superiority in relation to teachers increase the distance that exists between the teachers of elementary schools and high school teachers-researchers from the universities and strengthens the image of the inaccessible scientist.

Most Science Museums in Brazil provide this type of program to teachers, but some expand these activities to the general public, such as the "Bate Papo Hiperinteressante" at the Museum of Astronomy and Related Sciences (MAST) in Rio de Janeiro, offered on Sundays to families, that discusses scientific issues in an informal language; and the "Café com Prosa" of the Center of Science and Mathematics Teaching, of Federal University of Minas Gerais, which involves a short duration lecture followed by a open discussion with the public associated with an afternoon coffee break. This kind of short-duration, well-structured continuing professional development episodes, based on practical and interactive science teaching ideas can have long-term impact on those involved (Lydon and King, 2009).

\subsection{Production of Teaching Resources}

The Science Museums have contributed to teacher education with activities that encourage the production of didactic material, lesson plans for science practical classes, preparation and development of projects in school. These educational activities involve the strengthening of self-esteem and valuing of individual and collective capacity of teachers participating in the program. It is essential that the teacher has the autonomy to think about their lesson plans and find ways to put them into practice. In this sense, science museums have assisted teachers in organizing the steps for these proposals. Another important point is to offer alternatives to the suggestions of science teaching in textbooks, especially when those alternatives are proposed by the teachers participating in the formation program. As described by Astor-Jack et al. (2007), the informal science institutions staff focuses on the sources of knowledge as materials, exhibits and hands-on interactions and suggests that, given their experience and context, the practical aspects of objects yields the strongest potential for learning.

The "Education Workshops" program from the Museum of Science and ${ }^{2}$ Hiper Interesting Chat.

${ }^{3}$ Coffee with Prose. 
Technology (MCT) of the Catholic University of Rio Grande do Sul, is offered to teachers of elementary and middle school of science and math areas and students in undergraduate courses. A striking feature of the workshops is to discuss the specific topic proposed for a particular meeting based on the difficulties presented by the teachers to develop it in the classroom. Thus, the teaching and school environment are targets of much discussion during the meetings in order that any specific knowledge is discussed by teachers of the participating groups from the perspective of everyday school life. There is no material to support the activities of the workshops because they are organized based on a problem situation (real or fictional) that creates conflicts in the group, and from that problem, a discussion is developed and possible solutions are presented. During the planning of workshops, teachers are encouraged to plan and develop their own games and teaching resources, after extensive discussion of the scientific concepts involved, relationship with the school reality and feasibility of the material. Thus, the teachers prepare the learning resources and test them in the classroom, returning to the workshops with information on what was successful and what was not during the implementation with students. Then, a new discussion is established in the group to evaluate the game or the material functionality.

The Environmental Education Project of the Center of Scientific and Cultural Dissemination (CDCC) of the São Paulo University, involves a course for teachers. The content related to environmental issues and the problem of generation and final disposal of domestic solid waste are addressed in the form of classes. At the beginning of the course teachers can have wide information of local and global environmental issues, the need for waste reduction, reuse and recycling of materials, rights and duties of citizens. After this initial stage, teachers are encouraged to plan an environmental education project on domestic solid waste to be developed in school. During the course, the positive and negative aspects of the projects proposed by teachers and the planned steps are discussed with caution. After the development of lesson plans for teachers in a systematic way, some texts on research projects and environmental education are provided to participants. Following these readings, teachers develop their own projects, based on the information provided at the beginning of the course and on experience in the classroom and peculiarities of the neighborhood where the school is embedded.

The program for teacher education in the Science Space at Recife is a course for establishment of laboratories in public schools that were characterized as the Center of Reference of Sciences. The course has five modules for the development of themes related to the areas of physics, chemistry, mathematics and biology, discussion of the problems of science teaching and practice, preparation of didactic material to support laboratories and evaluation. From the suggestions of the teachers involved, experiments were designed to meet the specific needs of the working group suggested by the given topic. Along the development of new experiments, teachers are encouraged to create and develop teaching resources themselves, from simple elements present in the daily life of students. Several 
materials developed by the group are incorporated as replicas of the laboratories and the collection of the museum. The work done by the technical staff of the museum for the teachers education follows a methodology that involves the search for solutions to problem-situations, the preparation of simple science experiments, the discussion of results and reporting them to colleagues. Thus, teachers will not only create issues and proposals for experiments, but they are also advised to seek alternative materials for the laboratory and develop joint teaching themselves. The relationship between the researchers of the museum's technical staff and teachers provides information exchange and establishment of a mutual respect, since the proposed program is structured considering the teacher as an individual able to act with responsibility in the implementation of action teaching. In this way, Fraser et al. (2007) discuss that teacher empathy with project aims and their motivation to engage with ideas through reading and discussion were fundamental for transformational teacher learning.

These programs focus on changing teaching practice through reflection on the teaching work and development of initiatives for improving the quality of the teaching of science. All such materials are produced in the format of laboratory kits and/or educational games that support the practical classes. During the implementation of activities for the production of teaching materials, teachers socialize problems and experiences in everyday school life, reflecting on their teaching practices and the need for transformation of reality, however without further theoretical deepening in the area. The structure of programs can be assembled as a workshop, courses of middle and long-term and working groups. In any of the structures, the approach emphasizes content and methodology of teaching that could contribute to the modification of teaching practice.

\subsection{Teaching Advice}

The science museums that seek to follow the work done in school by teachers who passed the educational activity programs contribute to the process of education advising teacher in developing activities in the school environment, ensuring a continuity of relationship with technical staff and perpetuation of experience exchanging. Moreover, this advisory affect teacher's motivation to work as a modifier in the classroom, since after the formation process in the core of scientific information, teachers do not see themselves alone in school but supported by people who shared with him problems, ideas and solutions.

One example is the work of the Science Station of São Paulo University, through the Project "ABC Science Education-Hands-on/La main à la pâte" a French proposal for the teaching of science in the initial grades of basic education, developed in partnership with State Department of Education. The project provides the student the supervision and support of the teacher, hold a similar activity of scientific research, in which the researcher develops a problem, raise hypotheses about the problem, tests these hypotheses through observation and experimentation, reports the results, writes a scientific article, discloses the work 
to the academic community and, through discussion with peers, offers new hypotheses or concludes the research. Teachers, coordinators and teaching assistants have a technical-education program of continuing education consisting of monthly meetings with the Science Station staff throughout the year, to develop the design and implementation in the classroom. In addition to these meetings for training, the museum team follows the group of teachers in schools, at least once a month, depending on the school, usually during pedagogical collective working hours. In visits to schools points of specific interest to teachers are discussed such as who makes the difficulties of day-to-day in the classroom, the need for an update and the problems inherent to the school environment, in support of direction, dialogue with peers, lack of space for discussion, among others. For Nelson and Slavit (2007), dialogic inquiry in classroom-based data is a key element in teachers' professional growth.

\subsection{Socialization of Knowledge}

In programs where there is the formation of working groups to discuss a number of factors that affect the teaching and learning of science, science museums training processes contribute to the extent of these discussions and to encourage the expansion of the teachers' vision of the world. The exchange of information and experiences among the participants of the educational process and the museum staff makes the space of science centers and museums meeting places in favor of socialization of scientific and educational knowledge. While participating in a learning community, the rule is innovation and inquires in order to learn how to better serve students (Lieberman, 2009).

Through the theoretical study of issues related to science teaching, science museums help teachers to understand the teaching process more widely, particularly in the establishment of relations between the different ways of teaching science and the future possibilities of the student to become independent and critical about scientific information. The nuclei of science communication that go beyond and offer teachers texts, articles and books that discuss the education in Brazil considering the historical, economical, political, social and cultural rights, including a redemption of the social role of teaching collaborate to engender in teachers new mental frames and relations with the historical events that determine the current status of the Brazilian educational system, thereby enlarging the vision of world and awareness of teaching.

The programs developed by MCT (Citizen Project) and MAST (Workshop of Environmental Education Teaching) focus on changing the social reality and school from the organization of groups of teachers to discuss the problems faced in everyday teaching practice, the teaching of science and school curriculum. Both programs use the socio-environmental issues as a starting point to expand the vision of the world of teachers and promote discussions relevant to a self-criticism and reflection on the teaching and the political and social consequences of science teaching. In these programs, the technical team of the Science 
Museums act as mediators of the formation, leaving open the way for democratic participation of teachers and the management of activities. The issue of Education in Brazil is addressed in depth, especially in science and environmental education, the reasons for policies that support the current guidelines of the educational system, the conditions of teaching, the need for change in curriculum and pedagogical practice. That discussion is fostered by the reading of texts, articles and books on these subjects.

\section{Conclusion}

The science museums in Brazil are contributing to the teachers' education in different ways, offering options for public and varied demands. This contribution comes from the update of content, important and necessary to connect the teaching practice to technological and scientific innovations of the current world, and to strengthen the intellectual baggage of teachers through intensive discussions and readings based on theoretical education issues.

Generally the science museums suit seeking education proposals to teachers who attend these sites and using them as teaching resources to complement the lessons in school. Some proposals for training are the need to give teachers the space of the museum and the opportunities for interaction with visitors. Other programs seek to facilitate the relationship between the teacher and the school museum. Others seek to include teachers in the debate on the popularization of science and technology in the country, permeated by the bias of education in science and consolidation of citizenship.

Regardless of the purposes that lead Science Museums to propose teacher training programs as educational activities, it is important to highlight the contribution of these places as institutions of Science dissemination open to active participation of teachers.

\section{Acknowledgements}

CNPq (Conselho Nacional de Desenvolvimento Científico e Tecnológico) and PROPP/UFU for financial support.

\section{Conflicts of Interest}

The authors declare no conflicts of interest regarding the publication of this paper.

\section{References}

Astor-Jack, T., McCallie, E., \& Balcerzak, P. (2007). Academic and Informal Science Education Practitioner Views about Professional Development in Science Education. Science Education, 91, 604-628. https://doi.org/10.1002/sce.20205

Fahl, D. (2003). Marcas do ensino escolar de Ciências presentes em Museus e Centros de Ciências: Um estudo da Estação Ciência-São Paulo e do Museu Dinâmico de Ciências de Campinas (MDCC). Campinas: UNICAMP.

Faria, C. (2012). A Science Teacher Education Course in a Science Centre: A Successful 
Strategy to Empower Teachers to Master Museum Resources Exploration?, Electronic Journal of Science Education, 16, 1-13.

Fraser, C., Kennedy, A., Reid, L., \& Mckinney, S. (2007). Teachers' Continuing Professional Development: Contested Concepts, Understanding and Models. Professional Development in Education, 33, 153-169. https://doi.org/10.1080/13674580701292913

Gouvêa, G., Valente, M. E., Cazelli, S., \& Marandino, M. (2001). Redes Cotidianas de Conhecimentos e os Museus de Ciências. Parcerias Estratégicas, 11, 169-174.

Holliday, G. M., Lederman, N. G., \& Lederman, J. S. (2014). Comfort and Content: Considerations for Informal Science Professional Development. International Journal of Science Education, Part B, 4, 356-375. https://doi.org/10.1080/21548455.2013.855834

Jacobucci, D. F. C., Jacobucci, G. B., \& Megid Neto, J. (2009). Experiências de Formação de Professores em Centros e Museus de Ciências no Brasil. REEC. Revista Electrónica de Enseñanza de las Ciencias, 8, 118-136.

Laville, C., \& Dionne, J. (1999). A construção do saber: manual de metodologia da pesquisa em ciências humanas. Porto Alegre: Artmed, Belo Horizonte: Editora UFMG, 342 p.

Lieberman, J. (2009). Reinventing Teacher Professional Norms and Identities: The Role of Lesson Study and Learning Communities. Professional Development in Education, 35, 83-99. https://doi.org/10.1080/13674580802264688

Lüdke, M, \& André, M. (1986). Pesquisa em educação: abordagens qualitativas I (Temas básicos de educação e ensino). São Paulo: EPU, 44 p.

Lydon, S., \& King, C. (2009). Can a Single, Short Continuing Professional Development Workshop Cause Change in the Classroom? Professional Development in Education, 35, 63-82. https://doi.org/10.1080/13674580802264746

Melber, L. M., \& Cox-Petersen, A. M. (2005). Teacher Professional Development and Informal Learning Environments: Investigating Partnerships and Possibilities. Journal of Science Teacher Education, 16, 103-120. https://doi.org/10.1007/s10972-005-2652-3

Mortensen, M. F., \& Samrt, K. (2007). Free-Choice Worksheets Increase Students' Exposure to Curriculum during Museum Visits. Journal of Research in Science Teaching, 44, 1389-1414. https://doi.org/10.1002/tea.20206

Nelson, T. H., \& Slavit, D. (2007). Collaborative Inquiry among Science and Mathematics Teachers in the USA: Professional Learning Experiences through Cross-Grade, Cross-Discipline Dialogue. Professional Development in Education, 33, 23-39. https://doi.org/10.1080/13674580601157620

Patterson, T. (2021) Historians, Archivists, and Museum Educators as Teacher Educators: Mentoring Preservice History Teachers at Cultural Institutes. Journal of Teacher Education, 72, 113-125. https://doi.org/10.1177/0022487120920251

Phillips, M., Finkelstein, D., \& Wever-Frerichs, S. (2007). School Site to Museum Floor: How Informal Science Institutions Work with Schools. International Journal of Science Education, 29, 1489-1507. https://doi.org/10.1080/09500690701494084

Pierson, A. H. C., \& Neves, M. R. (2001). Interdisciplinaridade na Formação de Professores de Ciências: Conhecendo obstáculos. Revista Brasileira de Pesquisa em Educação em Ciências, 1, 120-131.

Selles, S. E. (2002). Formação Continuada e Desenvolvimento Profissional de Professores de Ciências: Anotações de um projeto. Ensaio Pesquisa em Educação em Ciências (Belo Horizonte), 2, 1-15. https://doi.org/10.1590/1983-21172000020206

Tran, L. U. (2006). Teaching Science in Museums: The Pedagogy and Goals of Museum Educators. Science Education, 91, 278-297. https://doi.org/10.1002/sce.20193 
Vianna, D. M., \& Carvalho, A. M. P. (2000). Formação Permanente: A necessidade da interação entre a Ciência dos cientistas e a Ciência da sala de aula. Ciência \& Educação (Bauru), 6, 31-42. https://doi.org/10.1590/S1516-73132000000100004 